\title{
Science Education and Student Results in Spain: A Multivariate Approach
}

\author{
Francisco López Rupérez ${ }^{1}$, Eva Expósito-Casas ${ }^{2}$ and Isabel García García ${ }^{3}$ \\ ${ }^{1,3}$ Cátedra de Políticas Educativas, Universidad Camilo José Cela, Madrid, Spain \\ ${ }^{2}$ Universidad Nacional de Educación a Distancia, Spain \\ ${ }^{1}$ franciscolopezruperez@gmail.com, ${ }^{2}$ evaexpositocasas@edu.uned.es, \\ ${ }^{3}$ isabel.garciagarcia@gmail.com
}

\begin{abstract}
Science education is considered one of the key elements for the development of skills and competencies for the economy and society of the 21 st century. Beyond its economic dimension, the quality of science teaching in compulsory education has a fundamental civic dimension: in the new context, it is necessary to adopt scientific reasoning and approaches and be able to position it in the face of political proposals whose evaluation will quite often require future scientific knowledge. In this context, for the first time PISA 2015 provides the results of all the Spanish autonomous communities on statistically representative samples at the regional level. This allows a territorialized diagnosis to be made on different aspects related to science education. In this work, we have identified a set of variables related to instruction whose influence on student performance in Sciences has been significant. For this reason, a multiple linear regression model has been used. This model has first been applied to the national sample and then to the samples from the seventeen autonomous communities. Moreover, based on PISA 2015 data, a dependent variable of a dichotomous nature has been defined, centered on predicting if 15-year-old students will or will not have STEM professions at 30 years of age. An analysis of Multivariate Binary Logistic Regression has been carried out at both the national and autonomous community level. The discussion of the results provides some reflections of interest for educational policies and teaching practices.
\end{abstract}

Keywords: PISA 2015, Science education, Performance in sciences, STEM vocation, Educational policies, Teaching practices

\section{Introduction}

Science education is a key element for preparing the future of individuals and societies in the 21 st century. The emergence of what K. Shwab [1] has called the "fourth industrial revolution" - a technological revolution that concerns physical, biological and digital systems and their interactions - is reinforcing the importance of STEM (Science, Technology, Engineering, Mathematics) teaching [2]. The impact of STEM on economic development and employment, both nationally and regionally is sufficiently established [3][4][5][6][7][8][9]. In this context, due to the strong link between science education and the development of both cognitive and non-cognitive skills required by the economy and employment in the present

Article history:

Received (September 26, 2019), Review Result (October 29, 2019), Accepted (December 5, 2019) 
century [10], the quality of science teaching in secondary education has become one of the fundamental requirements of future education. Student orientation towards STEM options in higher education, with a deficit in Spain that has been signaled by institutions [11], will depend on it. This perspective has been assumed by the Organization for Economic Cooperation and Development (OECD) in its PISA programme [12].

Beyond its economic dimension, the quality of science teaching in compulsory education has a main civic dimension, which is also linked to the evolution of the context and has been justified in PISA by the need for citizens to adopt scientific reasoning and approaches and to be able to position themselves in relation to political proposals whose evaluation requires a certain knowledge of science [11][13].

PISA 2015 has provided the results of all the Spanish regions for the first time ever (Autonomous Communities) with statistically representative samples of the corresponding population at the regional level. This allows territorialized diagnoses to be made for Spain on different aspects related to science education [14], in line with the previous perspective.

Considering the recognized influence of the quality of teaching on student performance [15][16][17], this work has identified a set of variables related to instruction, whose influence on performance in Science has resulted significant. A multiple linear regression model has been used for this. This model has first been applied to the national sample and to each of the samples of the seventeen Spanish autonomous communities before proceeding to the analyses corresponding to different subscales.

Furthermore, from PISA 2015 data, a dependent variable has been defined regarding the forecasts of whether 15-year-old students will or will not be in STEM professions at 30 years of age, and an analysis of Multivariate Binary Logistic Regression has been carried out, at the national level and at the level of the autonomous communities. Together with other independent variables, the collection of predictors used in the previous model has been considered.

The discussion of the results has shed light on educational policies and teaching practices for improvement and recommendations of interest for the two territorial levels considered.

\section{Methodology}

\subsection{Samples}

In the present study, the national PISA sample composed of 6,736 students and representative of the entire Spanish population of 15-year-old students has been used. Furthermore, the seventeen expanded samples corresponding to the autonomous communities and statistically representative of their respective school populations of that age level have been considered. [Table 1] presents the different extensions $(\mathrm{N})$ of the regional samples, as well as the percentages with respect to their respective populations.

\subsection{Tests and questionnaires}

The variables of interest in the present study have been measured through PISA tests and some of its questionnaires [18]. In relation to the tests, [Tables 2] and [Table 3], which have been prepared by the authors based on the information contained in the PISA 2015 database [12] - constitute two specification tables showing the distributions of all 184 items of the Science test by different subscales and by level of cognitive demand. 
Table 1. Extension of the samples of students corresponding to the seventeen Spanish autonomous communities and percentage with respect to their populations

\begin{tabular}{|c|c|c|}
\hline & $\mathrm{N}$ & $\%$ \\
\hline Andalucía & 1.813 & $4,6 \%$ \\
\hline Aragón & 1.798 & $4,6 \%$ \\
\hline Asturias & 1.790 & $4,6 \%$ \\
\hline Islas Baleares & 1.797 & $4,6 \%$ \\
\hline Canarias & 1.842 & $4,7 \%$ \\
\hline Cantabria & 1.924 & $4,9 \%$ \\
\hline Castilla y León & 1.858 & $4,8 \%$ \\
\hline Castilla-La Mancha & 1.889 & $4,8 \%$ \\
\hline Cataluña & 1.769 & $4,5 \%$ \\
\hline Comunidad Valenciana & 1.625 & $4,2 \%$ \\
\hline Extremadura & 1.809 & $4,6 \%$ \\
\hline Galicia & 1.865 & $4,8 \%$ \\
\hline Comunidad de Madrid & 1.808 & $4,6 \%$ \\
\hline Región de Murcia & 1.796 & $4,6 \%$ \\
\hline Comunidad Foral de Navarra & 1.874 & $4,8 \%$ \\
\hline País Vasco & 3.612 & $9,2 \%$ \\
\hline La Rioja & 1.461 & $3,7 \%$ \\
\hline
\end{tabular}

Source: Authors from PISA 2015 database.

Table 2. Distribution of total items in three PISA subscales related to competencies and types of knowledge: content, procedural and epistemic

\begin{tabular}{|c|c|c|c|c|}
\hline CompetencES & \multicolumn{4}{|c|}{ TypE of KNOWLEDGE } \\
\hline Content & Content & Procedural & Epistemic & Total \\
\hline Explain Phenomena Scientifically & 83 & 4 & 2 & 89 \\
\hline Physical Systems & 34 & 1 & - & 35 \\
\hline Living Systems & 30 & 3 & - & 33 \\
\hline Earth \& Space Systems & 19 & - & 2 & 21 \\
\hline Evaluate And Design Scientific Inquiry & 1 & 19 & 19 & 39 \\
\hline Physical Systems & - & 9 & 7 & 16 \\
\hline Living Systems & 1 & 10 & 7 & 18 \\
\hline Earth \& Space Systems & - & - & 5 & 5 \\
\hline Interpret Data And Evidence Scientifically & 14 & 37 & 5 & 56 \\
\hline Physical Systems & 4 & 6 & - & 10 \\
\hline Living Systems & 3 & 18 & 2 & 23 \\
\hline Earth \& Space Systems & 7 & 13 & 3 & 23 \\
\hline Physical Systems. Total & 38 & 16 & 7 & 61 \\
\hline Living Systems. Total & 34 & 31 & 9 & 74 \\
\hline Earth \& Space Systems. Total & 26 & 13 & 10 & 49 \\
\hline Total & 98 & 60 & 26 & 184 \\
\hline
\end{tabular}

Source: Authors based on the information of spreadsheets C2.1 and C2.2 [18] 
Table 3. Distribution of total items by types of knowledge and scientific competences according to their level of cognitive demand

\begin{tabular}{|c|c|c|c|c|}
\hline Type Of Knowledge & \multicolumn{4}{|c|}{ Cognitive Demand } \\
\hline Scientific Competence & Low & Medium & High & Total \\
\hline Content & 44 & 50 & 4 & 98 \\
\hline Explain Phenomena Scientifically & 41 & 40 & 2 & 83 \\
\hline Evaluate And Design Scientific Inquiry & - & 1 & - & 1 \\
\hline Interpret Data And Evidence Scientifically & 3 & 9 & 2 & 14 \\
\hline Procedural & 9 & 43 & 8 & 60 \\
\hline Explain Phenomena Scientifically & - & 1 & 1 & 2 \\
\hline Evaluate And Design Scientific Inquiry & 2 & 13 & 4 & 19 \\
\hline Interpret Data And Evidence Scientifically & - & - & 6 & 29 \\
\hline Epistemic & 3 & 20 & 3 & 26 \\
\hline Explain Phenomena Scientifically & - & 2 & - & 2 \\
\hline Evaluate And Design Scientific Inquiry & 3 & 14 & 2 & 19 \\
\hline Interpret Data And Evidence Scientifically & & 4 & 1 & 5 \\
\hline Explain Phenomena Scientifically. Total & 5 & 28 & 6 & 39 \\
\hline Evaluate And Design Scientific Inquiry. Total & 42 & 43 & 4 & 89 \\
\hline Interpret Data And Evidence Scientifically. Total & 9 & 42 & 5 & 56 \\
\hline Total & 56 & 113 & 15 & 184 \\
\hline
\end{tabular}

Source: Authors based on the information of spreadsheets C2.1 and C2.2 [18]

In order to specify the values in terms of microdata, the questionnaires used in PISA 2015 [18] have also been used here and linked to some of the variables related to the instruction that will be used later as predictors in our multivariate regression models. These questionnaires have allowed us to value the following aspects:

- Scientific vocation

- Economic, social and cultural status (ESCS)

- Disciplinary climate in science classes

- Teacher support in science classes of student choice

- Inquiry-based science teaching and learning practices

- Teacher-directed science instruction

- Enjoyment of science

Annex A of the publication mentioned above shows the complete formulation of the different questionnaires applied in PISA 2015 [18]. The previous list of variables refers only to a part of these questionnaires.

\subsection{Variables and analysis procedures}

The dependent and independent variables that have been managed in this study are listed below:

- Independent variables: Disciplinary climate in science classes (DISCLISC), Teacher support in science classes of student choice (TEACHSUP), Inquiry-based science teaching and learning practices (IBTEACH), Teacher-directed science instruction (TDTEACH), Enjoyment of science (JOYSCI), and Economic, Social and Cultural Status (ESCS). 
- Dependent variables: Student Performance in Science -global and by subscales- and STEM vocation. *

As for the analysis procedures, a multiple linear regression model has been used for relating performance in science - global and by subscales - with the independent variables described above, for the two territorial levels considered: Spain as a whole and the autonomous communities.

Moreover, and given the dichotomous nature of the STEM vocation variable (STEM / nonSTEM), a second model of Multivariate Binary Logistic Regression has been used, including the previous collection of predictors plus the variables sex, ESCS and level of performance in Science. The corresponding methodological basis [19] consists in evaluating the effect of the factors on the outcome (predicted value). The prediction that is based on the regression model is compared with the observed value: if it coincides, the case is considered correctly classified; otherwise it is considered an incorrect classification. The more cases a model correct classifies, the more explanatory it will be which is proof of the importance of the independent variables considered when predicting the event. The fit of the model is accepted when more than $50 \%$ of the cases are classified correctly.

\section{Results}

\subsection{Influence on performance in Science and on its components of instruction-related variables}

The application of the first model (1) to the sample at the national level shows an acceptable goodness of fit, with an explained variance percentage of $29 \%\left(\mathrm{R}^{2}=0.29\right)$ and a statistically significant contribution of all the predictors included. The appreciable influence of the variable Enjoyment of science (beta coefficient=25.51) in the prediction of performance in science, as well as of the ESCS variable (beta coefficient=22.61) should be noted. The variables Teacher support in science classes of student choice (beta coefficient=-7.71) and Inquiry-based science teaching and learning practices (beta coefficient=-9.37) have a negative effect.

Performance in Science $=\mathrm{f}$ (ESCS, DISCLISC, TEACHSUP, IBTEACH, TDTEACH, JOYSCI) (1).

When this same model is applied to each of the samples from the different autonomous communities, once again an acceptable goodness of fit is observed for all of them, with small nuances related to the differential influence of the variables introduced as predictors. [Table 4] presents a summary of the results obtained from the application of the model (1) to the different autonomous communities. The percentage of total variance of the performance in Science explained oscillates between $31.7 \%$ for Murcia and $22.0 \%$ for Galicia. This table shows the direct or inverse relationship of the independent variable with the global performance in Science, as well as its magnitude.

\footnotetext{
* STEM occupations include categories 21 (Science and engineering professionals), 25 (Information and communications technology professionals) and 31 (Science and middle level engineering professionals) of the International Classification Occupational Uniform, ISCO-08. Therefore, for the definition of this variable, we chose to ignore the answers to the Health Sciences box of the corresponding questionnaire.
} 
Table 4. Summary of the results obtained from the application of the model (1) to the different autonomous communities

\begin{tabular}{|c|c|c|c|c|c|c|c|}
\hline & \multicolumn{7}{|c|}{ Statistically significant variables } \\
\hline $\begin{array}{c}\text { Autonomous } \\
\text { Community }\end{array}$ & $\mathrm{R}^{2}$ & ESCS & $\begin{array}{c}\text { Disciplinar } \\
\text { y Climate } \\
\text { In Science } \\
\text { Classes }\end{array}$ & $\begin{array}{c}\text { Teacher } \\
\text { Support In } \\
\text { Science Classes } \\
\text { Of Student } \\
\text { Choice }\end{array}$ & $\begin{array}{c}\text { Inquiry-Based } \\
\text { Science } \\
\text { Teaching And } \\
\text { Learning } \\
\text { Practices }\end{array}$ & $\begin{array}{c}\text { Teacher- } \\
\text { Directed } \\
\text { Science } \\
\text { Instruction }\end{array}$ & $\begin{array}{c}\text { Enjoymen } \\
\text { t Of } \\
\text { Science }\end{array}$ \\
\hline AndalucíA & 30,3 & 20.18 & 6,22 & $-8,55$ & $-11,82$ & 15,13 & 26,41 \\
\hline AragÓN & 26,5 & 22,96 & 5,035 & $-6,51$ & $-9,33$ & 11,55 & 22,77 \\
\hline Asturias & 29,6 & 26,70 & 7,38 & $-7,25$ & $-9,04$ & 13,83 & 20,62 \\
\hline Islas Baleares & 25,0 & 20,34 & 10,72 & $-6,57$ & $-7,63$ & 9,37 & 23,48 \\
\hline Canarias & 26,9 & 24,39 & 8,44 & $-11,11$ & $-8,21$ & 11,35 & 19,83 \\
\hline Cantabria & 23,6 & 18,09 & 5,77 & $-6,74$ & $-10,32$ & 11,61 & 23,53 \\
\hline $\begin{array}{c}\text { Castilla Y } \\
\text { LeÓN }\end{array}$ & 25,5 & 16,57 & 7,46 & $-9,02$ & $-13,64$ & 11,59 & 27,48 \\
\hline $\begin{array}{c}\text { Castilla-La } \\
\text { Mancha }\end{array}$ & 26,2 & 20,63 & 11,83 & $-9,13$ & $-11,29$ & 11,40 & 21,85 \\
\hline Cataluña & 30,0 & 23,81 & 5,28 & $-6,82$ & $-10,56$ & 9,26 & 27,16 \\
\hline $\begin{array}{c}\text { Comunidad } \\
\text { Valenciana }\end{array}$ & 27,7 & 19,00 & 3,72 & $-4,28$ & $-6,20$ & 5,54 & 26,29 \\
\hline Extremadura & 26,6 & 18,66 & 4,20 & $-8,86$ & $-6,96$ & 12,07 & 25,60 \\
\hline Galicia & 22,0 & 14,01 & 7,42 & $-6,09$ & $-11,51$ & 8,47 & 27,44 \\
\hline $\begin{array}{c}\text { Comunidad } \\
\text { De Madrid }\end{array}$ & 27,9 & 26,47 & 5,01 & $-10,97$ & $-5,68$ & 11,46 & 23,78 \\
\hline $\begin{array}{c}\text { RegiÓN De } \\
\text { Murcia }\end{array}$ & 31,7 & 27,25 & 3,15 & $-8,07$ & $-5,60$ & 6,92 & 23,34 \\
\hline $\begin{array}{c}\text { Com. Foral } \\
\text { De Navarra }\end{array}$ & 29,5 & 25,31 & 5,33 & $-3,22$ & $-9,73$ & 7,17 & 24,99 \\
\hline PaÍS Vasco & 24,6 & 17,66 & 5,13 & $-3,81$ & $-7,38$ & 4,86 & 25,51 \\
\hline \begin{tabular}{c} 
La Rioja \\
\hline
\end{tabular} & 27,9 & 21,31 & 3,38 & $-10,23$ & $-7,76$ & 11,92 & 26,37 \\
\hline
\end{tabular}

In order to deepen the previous results, the different subscales of competences in Science established in PISA 2015 (Explain Phenomena Scientifically, Evaluate and Design Scientific Inquiry, Interpret Data and Evidence Scientifically) have been taken into consideration. The subscales of knowledge of contents (Knowledge Subscale of Science - Content), procedures and epistemic knowledge (Knowledge Subscale of Science - Procedural \& Epistemic), and systems of science (Physical Systems - Living Systems - Earth \& Space Systems) have also been considered [20] Multiple regression models similar to the one presented above have been used for this purpose and have been applied to the national sample. In this case, each of the aforementioned science subscales have been considered as a dependent variable in each of these models and the variables related to the instructional methodologies mentioned above have been introduced as predictors, together with the ESCS. [Table 5] shows a summary of the results of the application of the model for each of the dependent variables. The results by autonomous communities are not presented because the differences between them have proved to be scarcely relevant in this case. 
Table 5. Summary of the results of the application of the subscale model for the national sample

\begin{tabular}{|c|c|c|c|c|c|c|c|}
\hline Subscales & $\mathrm{R}^{2}$ & $\begin{array}{c}\text { ESC } \\
\mathrm{S}\end{array}$ & $\begin{array}{l}\text { Disciplinar } \\
\text { y climate } \\
\text { in science } \\
\text { classes }\end{array}$ & $\begin{array}{c}\text { Teacher } \\
\text { support in } \\
\text { science classes } \\
\text { of students } \\
\text { choice }\end{array}$ & $\begin{array}{l}\text { Inquiry-based } \\
\text { science } \\
\text { teaching and } \\
\text { learning } \\
\text { practices } \\
\end{array}$ & $\begin{array}{l}\text { Teacher- } \\
\text { directed } \\
\text { science } \\
\text { instruction }\end{array}$ & $\begin{array}{l}\text { Enjoyment } \\
\text { of science }\end{array}$ \\
\hline $\begin{array}{c}\text { Competency } \\
\text { Subscale of Science } \\
\text { - Explain } \\
\text { Phenomena } \\
\text { Scientifically }\end{array}$ & 29.2 & 22.45 & 4.47 & -8.09 & -8.82 & 10.92 & 27.75 \\
\hline $\begin{array}{c}\text { Competency } \\
\text { Subscale of Science } \\
\text { - Evaluate and } \\
\text { Design Scientific } \\
\text { Enquiry }\end{array}$ & 27.4 & 22.93 & 7.91 & -8.71 & -10.22 & 11.01 & 22.88 \\
\hline $\begin{array}{c}\text { Competency } \\
\text { Subscale of Science } \\
\text { - Interpret Data and } \\
\text { Evidence } \\
\text { Scientifically }\end{array}$ & 27.7 & 23.21 & 6.45 & -7.43 & -10.63 & 11.32 & 24.89 \\
\hline $\begin{array}{c}\text { Knowledge } \\
\text { Subscale of Science } \\
\text { - Content }\end{array}$ & 29.4 & 22.24 & 4.67 & -8.30 & -9.09 & 10.68 & 27.72 \\
\hline $\begin{array}{c}\text { Knowledge } \\
\text { Subscale of Science } \\
\text { - Procedural \& } \\
\text { Epistemic }\end{array}$ & 28.2 & 23.26 & 7.25 & -7.47 & -10.17 & 10.54 & 24.41 \\
\hline $\begin{array}{l}\text { System Subscale of } \\
\text { Science - Physical }\end{array}$ & 28.8 & 23.16 & 6.47 & -7.50 & -8.22 & 9.95 & 25.95 \\
\hline $\begin{array}{l}\text { System Subscale of } \\
\text { Science - Living }\end{array}$ & 28.3 & 23.54 & 6.09 & -8.82 & -10.60 & 10.47 & 26.05 \\
\hline $\begin{array}{l}\text { System Subscale of } \\
\text { Science - Earth \& } \\
\text { Science }\end{array}$ & 28.5 & 22.21 & 5.35 & -7.07 & -10.27 & 11.63 & 25.49 \\
\hline
\end{tabular}

Source: Authors

The model has shown a good fit for all subscales, with a percentage of variance explained between 29.2\% of the Competency Subscale of Science - Explain Phenomena Scientifically and $27.7 \%$ of Competency Subscale of Science - Evaluate and Design Scientific Enquiry. The pattern of association of the predictors for each of the variables considered as dependent, and identified as subscales in Table 5, has been analogous to the preceding one, which reinforces the consistency of the model. Although the different values of $\mathrm{R}^{2}$ show small variations between them, it is the competence "Explain the phenomena scientifically" $\left(\mathrm{R}^{2}=29.2\right)$ and the "Knowledge of contents" $\left(\mathrm{R}^{2}=29.4\right)$ of the variables that are best explained by our model.

\subsection{Science teaching and STEM vocations}

For the reasons mentioned above, it was decided to carry out a Multivariate Binary Logistic Regression, keeping the same predictors of the previous model and adding the variables sex and level of performance in Science, a variable that considers the 6 levels established in PISA 2015. This modality of regression allows us to express the probability of an event occurring (STEM/non-STEM vocation), as a function of the independent variables considered relevant or influential. 
It can be seen that the model is statistically significant, and so is the effect of all the variables introduced. Thus, the values of the $\mathrm{R}^{2}$ statistics of Cox and Snell and $\mathrm{R}^{2}$ of Nagelkerke are between $11 \%$ and $17.8 \%$ (see Table 6). The calculation of the overall percentage correctly classified with the model yields a figure of $81.5 \%$, that is, it is able to correctly predict the STEM / non-STEM vocation in $81.5 \%$ of the cases. All the variables included in the equation have a significant effect on the STEM vocation (sig. <0.05). Additionally, odds ratios ${ }^{*}$ inform us of the strength of the relationship: the further away from 1 , the stronger the relationship. In our case, and in the order of the strength of the relationship with the STEM vocation, the first variable would be sex, followed by the level of performance in Science and enjoyment of science below. [Table 6] shows the results of applying this binary logistic regression model to each of the seventeen autonomous communities.

Table 6. Summary of the results obtained from applying the binary logistic regression model to each of the autonomous communities

\begin{tabular}{|c|c|c|c|c|}
\hline \multirow{2}{*}{$\begin{array}{l}\text { Autonomous } \\
\text { Community }\end{array}$} & \multirow{2}{*}{$\begin{array}{l}\text { Sig. of } \\
\text { model }\end{array}$} & \multicolumn{2}{|c|}{ Explained Variance $(\%)$} & \multirow{2}{*}{$\begin{array}{c}\% \\
\text { classified correctly } \\
\text { (global) }\end{array}$} \\
\hline & & $\mathrm{R}^{2}$ Cox y Snell & $\mathrm{R}^{2}$ Nagelkerke & \\
\hline Andalucía & $\cdot$ & 12.5 & 21.4 & 85 \\
\hline Aragón & $\cdot$ & 8.4 & 13.6 & 81.4 \\
\hline Asturias & $\bullet$ & 13.2 & 20.2 & 78 \\
\hline Islas Baleares & $\bullet$ & 10.2 & 17.1 & 82.7 \\
\hline Canarias & $\bullet$ & 6.5 & 11.8 & 86.4 \\
\hline Cantabria & $\cdot$ & 10.6 & 17.6 & 82.4 \\
\hline Castilla y León & $\bullet$ & 8.5 & 13.5 & 80.9 \\
\hline Castilla-La Mancha & $\bullet$ & 8.5 & 14.3 & 82.9 \\
\hline Cataluña & $\cdot$ & 10.3 & 15.9 & 78.1 \\
\hline Comunidad Valenciana & $\cdot$ & 11.8 & 19.2 & 81.4 \\
\hline Extremadura & $\cdot$ & 10.4 & 18.3 & 85.7 \\
\hline Galicia & $\cdot$ & 14.4 & 22.8 & 81.4 \\
\hline Comunidad de Madrid & $\cdot$ & 13.1 & 19.7 & 76.4 \\
\hline Región de Murcia & $\cdot$ & 11.2 & 18.7 & 83.2 \\
\hline Com. Foral de Navarra & $\bullet$ & 13.5 & 21.3 & 81.4 \\
\hline País Vasco & $\cdot$ & 13.5 & 21 & 79.3 \\
\hline La Rioja & $\cdot$ & 13.4 & 21.8 & 81.5 \\
\hline
\end{tabular}

Source: Authors

[Table 7] summarises the different variables that have been significant in relation to the STEM vocation variable in each of the autonomous communities. It shows that there are three statistically significant variables in all models: sex, level of performance in Science and enjoyment of science. This result is consistent with those obtained in our previous analyses and points to the nature of the educational policies and teaching practices on which it is necessary to act in order to prepare Spanish society for some of the challenges of the present century. This issue will be considered in the Discussion.

\section{Discussion}

The analysis of the results from the application of the first model to the different samples reveals, in the first place, an inverse and statistically significant relationship with the

\footnotetext{
* The odds ratio is defined as the ratio between the odds corresponding to an event under a certain condition and the odds corresponding to the same event under another conditions [19].
} 
performance of the variable Teacher support in a science classes of student choice for all autonomous communities. This result, apparently counterintuitive, could be explained by the fact that it is the students who start from a situation of greater disadvantage that generally receive the most support.

Table 7. Summary of the different variables whose relationship with the STEM vocation variable (Yes / No) has been statistically significant for each of the autonomous communities

\begin{tabular}{|c|c|c|c|c|c|c|c|c|}
\hline $\begin{array}{l}\text { Autonomous } \\
\text { Community }\end{array}$ & Sex & $\begin{array}{l}\text { Level of } \\
\text { Science }\end{array}$ & ESCS & DISCLISC & $\begin{array}{c}\text { TEACHS } \\
\text { UP }\end{array}$ & IBTEACH & TDTEACH & JOYSCI \\
\hline Andalucía & • & & - & • & • & - & & - \\
\hline Aragón & • & - & & & & & & - \\
\hline Asturias & - & • & • & & • & & & - \\
\hline Islas Baleares & • & • & & • & - & & - & - \\
\hline Canarias & • & • & & • & - & & • & - \\
\hline Cantabria & - & - & & & & & & - \\
\hline $\begin{array}{l}\text { Castilla y } \\
\text { León }\end{array}$ & - & - & & • & & & & • \\
\hline $\begin{array}{l}\text { Castilla-La } \\
\text { Mancha }\end{array}$ & - & - & & & & - & • & - \\
\hline Cataluña & $\cdot$ & $\cdot$ & • & • & & • & & $\mathrm{v}$ \\
\hline $\begin{array}{c}\text { Com. } \\
\text { Valenciana }\end{array}$ & • & • & • & • & & • & & - \\
\hline Extremadura & • & • & • & & & • & & • \\
\hline Galicia & • & $\cdot$ & • & & • & $\cdot$ & • & - \\
\hline $\begin{array}{l}\text { Comunidad de } \\
\text { Madrid }\end{array}$ & • & - & - & $\bullet$ & - & $\bullet$ & • & - \\
\hline $\begin{array}{l}\text { Región de } \\
\text { Murcia }\end{array}$ & • & • & & & & • & • & - \\
\hline $\begin{array}{l}\text { Com. Foral de } \\
\text { Navarra }\end{array}$ & • & - & & & • & & & • \\
\hline País Vasco & • & $\cdot$ & & & • & & $\cdot$ & - \\
\hline La Rioja & • & - & & • & & & & - \\
\hline
\end{tabular}

It could be shocking to the staunch defenders of the "new methodologies" that Teacherdirected science instruction presents, in a systematic way in all the autonomous communities and for the different subscales, a direct and statistically significant relationship, while Inquirybased science teaching and learning practices show a relationship with performance of an inverse nature. This result, which is aligned with that obtained by PISA 2015 for the international sample [12] as well as by other researchers for the national sample [14], is compatible with the evidence available in relation to the influence of different methodologies, precisely in the field of science, on student performance [21] and, specifically, with that of 
"Project-based learning" [22]. This warns of the need to wisely manage these resources, which are valuable for science education if they are integrated into a didactic, composed and modular strategy that takes into account the individual needs of students and their context variables.

Similar conclusions are drawn from secondary analyses carried out in the McKinsey \& Co. study on the data from PISA 2015, with the help of the machine learning artificial intelligence procedure [23]. Based on the results obtained, the authors propose as generally more favourable a mixed methodological model: "Overall, our analysis suggests that systems should aim to balance inquiry-based methods with sufficient teacher-directed instruction to ensure that teachers are able to explain scientific concepts clearly, and that students have sufficient mastery of content to fully benefit from inquiry-based teaching" (p.10). However, it is worth noting the existence of aptitude-treatment interaction [24] between the levels of performance in Science of the different regions considered in the study - Asia, Europe, Latin America, Middle East / North Africa and North America - and each of these two methodological orientations, so that direct instruction is more effective in regions with lower science performance. As the authors point out, it is very likely that for these innovative methodologies to be effective, the student must have a sufficiently consolidated structured knowledge that is reflected, in this type of analysis, at higher levels of scores in the PISA tests.

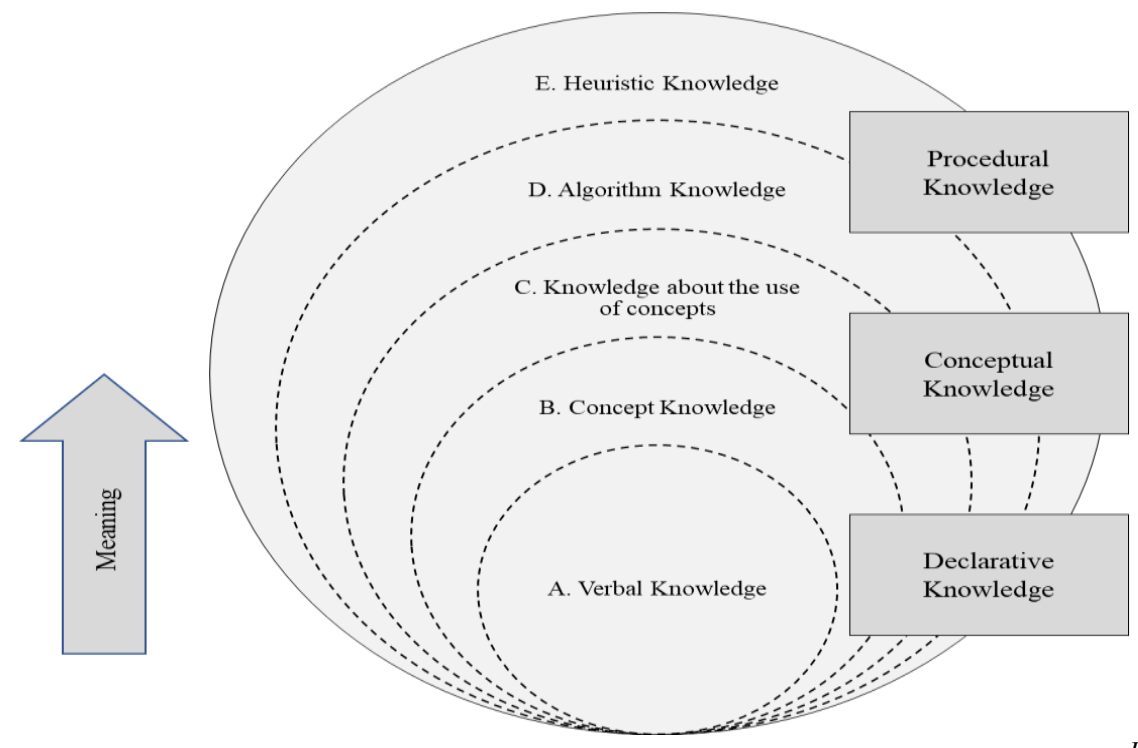

Fuente: [25]

Figure 1. A hierarchical layer model for scientific knowledge in the school environment

This tentative conclusion is consistent with a hierarchical model of scientific knowledge in the school environment, such as the one represented through a scheme of layers in [Figure 1], whose consequences at the level of science teaching are quite straightforward. As we have pointed out elsewhere: "The increase in meaning - which occurs, in principle, in the direction of increasing inclusion - defines, in fact, a round trip that also in this case is much more similar to a cyclic process than to a linear one. Thus, the gain of conceptual meaning improves verbal knowledge, the application of the concepts improves their meaning, which in turn improves verbal knowledge, etc. [25]. This conceptual model, which emerges from science education, is compatible with the scheme proposed on broad empirical bases from 
psychology [26] by the US National Research Council [27]for the cognitive skills and abilities of the 21 st century.

Regarding the conclusions derived from the application of the Multivariate Binary Logistic Regression models, a detailed analysis of [Table 7] allows us to guide the most plausible decisions made by educational administrations to operate on those variables that are susceptible to intervention, either by policymakers, or by schools themselves. Thus, for example, in the two extreme cases of [Table 7] - Aragon and the Community of Madrid, the Community of Madrid could consider the largest possible number of 'malleable' predictors that is, those on which one can intervene, whose association with the STEM vocation has proved significant for all of them; while Aragon could try to focus on improving the level of performance in Science and on the enjoyment of students with scientific learning.

The fact that the association between the variable STEM vocation and the variables level of performance in Science, enjoyment of Science and sex has been significant for all autonomous communities, suggests that reflection is needed on how to act on each of these three predictors. In previous works [28][29] researchers suggested a set of educational policies and teaching practices that would probably increase STEM vocations. Some of them are compatible with the new empirical evidence generated from a multivariate approach in this study.

\section{References}

[1] K. Shwab, "Cuatro principios de liderazgo de la cuarta revolución industrial," World Economic Forum, Available in www.weforum.org/es/agenda/2016/10/cuatro-principios-de-liderazgo-de-la-cuarta-revolucionindustrial, (2016)

[2] Fundación Telefónica, "Incrementar las vocaciones STEM entre los jóvenes," Available in https://top100desafio.fundaciontelefonica.com/incrementar-las-vocaciones-stem-entre-los-jovenes, (2014)

[3] Council of the European Union, "Conclusiones del Consejo," de 12 de mayo de 2009, sobre un marco estratégico para la cooperación europea en el ámbito de la educación y la formación (ET 2020), OJC 119, 28/5/2009, pp.2-10, (2009)

[4] D. Langdon and G. McKittrick, D. Beede, B. Khan, and M. Doms, "STEM: good jobs now and for the future," Department of Commerce, Economics and Statistics Administration, Washington: U.S., (2011)

[5] Royal Academy of Engineering, "Econometrics of engineering skills project," Jobs and growth: the importance of engineering skills to the UK economy, Royal Academy of Engineering, London, Available in https://www.raeng.org.uk/publications/reports/jobs-and-growth, (2012)

[6] EU STEM Coalition, Available in http://www.stemcoalition.eu, (2015)

[7] CEDEFOP, "Skill shortage and surplus occupations in Europe," European Centre for the Development of Vocational Training, Thessaloniki, Greece, (2016)

[8] WEF, "The future of jobs employment, skills and workforce strategy for the fourth industrial revolution," World Economic Forum, Available in http://www3.weforum.org/docs/WEF_Future_of_Jobs.pdf, (2016)

[9] E. Reig Martínez, F. Pérez García, J. Quesada Ibáñez, I. Serrano Martínez, C. Albert Pérez, C. Benages Candau, J. Pérez Ballester, and J. Salamanca Gonzales, "La competitividad de las regiones españolas ante la Economía del Conocimiento," IVIE-Fundación BBVA, Valencia, Available in https://www.fbbva.es/wpcontent/uploads/2016/11/Informe_final_Economia_Conocimiento.pdf, (2016)

[10] T.J. Kautz, J.J. Heckman, R. Diris, B. Weel, and L. Borghans, "Fostering and measuring skills: Improving cognitive and non-cognitive skills to promote lifetime success," OECD Education Working Papers, no.110, OECD Publishing, Paris, (2014) DOI:10.1787/5jxsr7vr78f7-en 
[11] J.M. Cavero Clerencia and D. Ruiz Quejido, "Educación para la innovación y el emprendimiento: Una educación para el futuro. Recomendaciones para su impulse," Real Academia de Ingeniería, Madrid Available in http://www.raing.es/sites/default/files/EDUCACION_PARA_INNOVACION_Web.pdf, (2017)

[12] OECD, "PISA 2015 results (Volume II): Policies and practices for successful schools," PISA, OECD Publishing, Paris, (2016) DOI:10.1787/9789264267510-en

[13] European Commission, "Science education for responsible citizenship," Report to the European Commission of the Expert Group on Science Education. European Commission, Brussels, Available in https://ec.europa.eu/research/swafs/pdf/pub_science_education/KI-NA-26-893-EN-N.pdf, (2015)

[14] J.M. Rodríguez-Mantilla, M.J. Fernández-Díaz, and G. Jover Olmeda, "PISA 2015: Predictores del rendimiento en ciencias en españa. revista de educación,” 380. Abril-junio 2018, pp.75-102, (2017) DOI: 10.4438/1988-592X-RE-2017-380-373.

[15] J. Hattie, "Teachers make a difference: What is the research evidence?" Australian Council for Educational Research Annual Conference on: Building Teacher Quality, October 2003, pp.1-17, Available in https://research.acer.edu.au/cgi/viewcontent.cgi?article=1003\&context=research_conference_2003, (2003)

[16] J. Hattie, "Visible learning: A synthesis of over 800 meta-analysis relating to achievement," Routledge, London, (2009)

[17] J. Hattie, "What works best in education: The politics of collaborative expertise," Pearson, London, (2015)

[18] OECD, "PISA 2015 assessment and analytical framework: science, reading, mathematics and financial literacy,” OECD Publishing, Paris, (2016) DOI:10.1787/9789264255425-en

[19] L. C. Silva Ayçaguer and I.M. Barroso Utra, "Regresión logística,” La Muralla, Madrid, (2004)

[20] OECD, "PISA 2015 results," Excellence and equity in education, vol.I. OECD Publishing, Paris, Available in https://www.oecd-ilibrary.org/education/pisa-2015-results-volume-i_9789264266490-en, (2016)

[21] E. López López, "El mastery learning a la luz de la investigación educative," Revista de Educación, 340, Mayo-agosto, pp.625-665, (2006)

[22] J. W. Thomas, "A review of research on project-based learning," Supported by The Autodesk Foundation 111 McInnis Parkway San Rafael, California, Available in http://www.bie.org/index.php/site/RE/ pbl_research/29,(2000)

[23] M. Mourshed, M. Krawitz, and E. Dorn, "How to improve student educational outcomes: New insights from data analytics," Available in https://www.mckinsey.com/industries/social-sector/our-insights/how-toimprove-student- educational-outcomes-new-insights-from-data-analytics, (2017)

[24] L. J. Cronbach and R.E. Snow, "Aptitudes and instructional methods: A handbook for research on interactions,” Irvington, New York, Available in http://www.revistaeducacion.mec.es/re340/re340_23.pdf, (1977)

[25] F. López Rupérez, Más allá de las partículas y de las ondas, "Una propuesta de inspiración epistemológica para la educación científica," Ministerio de Educación y Ciencia, Madrid, Available in https://es.scribd.com/document/238691032/Lopez-Ruperez-Mas-Alla-de-Las-Particulas-y-Las-Ondas, (1994)

[26] J. B. Carroll, "Human cognitive abilities,” Cambridge University Press, New York, (1993)

[27] National Research Council, "Education for life and work: Developing transferable knowledge and skills in the $21^{\text {st }}$ century," Committee on Defining Deeper Learning and $21^{\text {st }}$ Century Skills, (2012)

[28] F. López Rupérez, I. García García, and E. Expósito-Casas, "Performance in science, epistemic conceptions, and STEM vocations in Spain's autonomous communities: Evidence from PISA 2015, improvement policies, and practices," Revista Española de Pedagogía, vol.77, no.272, January-April, pp.5-27, Available in https://orcid.org/0000-0002-9884-6148, (2018)

[29] F. López Rupérez, E. Expósito-Casas, and I. García García, "Science education and gender gap in Spain," Secondary analyses from PISA 2015 and recommendations for the improvement, Revista Bordón, (2019) 


\section{Authors}

\section{Francisco López Rupérez}

Cátedra de Políticas Educativas. Universidad Camilo José Cela.

\section{Eva Expósito-Casas}

Universidad Nacional de Educación a Distancia

\section{Isabel García García}

Cátedra de Políticas Educativas. Universidad Camilo José Cela 
Science Education and Student Results in Spain: A Multivariate Approach

This page is empty by intention. 